\title{
Os Simpósios dos Arquivos Brasileiros de Oftalmologia
}

\author{
Harley E. A. Bicas
}

Comentar o Simpósio dos Arquivos Brasileiros de Oftalmologia ocorrido em Salvador, durante o XXXII Congresso Brasileiro de Oftalmologia caberia, por justiça, no editorial do número 5, o imediatamente subseqüente. Mas, então, a importância daquela reunião ficaria relativamente descaracterizada, ao ser aludida entre tantas outras novidades apresentadas naquela oportunidade. Em separado, ainda que só agora, seu valor ganha o merecido relevo.

Comecemos pelo que vem historicamente acontecendo: foi em 1998, no Congresso de Prevenção da Cegueira e Reabilitação Visual, no Rio de Janeiro, que os A.B.O. receberam, pela primeira vez, sala e espaço na grade de programação para expor seus projetos e discutir propostas. Desde então essa prerrogativa incorporou-se aos eventos seguintes e, alentadoramente, com aceitação crescente, não apenas pelos organizadores dos Congressos mas também pelos assistentes à reunião. De fato, de horários de difícil atendimento (como as oito da manhã, no primeiro dia do Congresso, durante toda a balbúrdia de inscrições, etc.) passamos a ter, outorgados, os de dias mais "nobres" (por exemplo, o segundo, com os congressistas já conhecendo o recinto e mais calmos quanto ao que escolher) e com maior duração. Neste Congresso de Salvador, das duas horas tradicionais, chegou-se a quatro para o desenvolvimento dos assuntos. Cabe sobretudo um agradecimento sincero aos organizadores desses Congressos pela elevada compreensão quanto à importância dos Arquivos Brasileiros de Oftalmologia, como legítimo órgão de preservação da ciência e da memória de nossa especialidade. E, ainda, pela oportunidade concedida para a difusão de conhecimentos sobre processos editoriais e afins.

Realmente, mesmo que se entenda o propósito principal de um Congresso como o de apresentação de aspectos práticos e referentes a temas de aplicação (procedimentos diagnósticos e terapêuticos sobre glaucoma, catarata, estrabismo, tumores, vícios de refração e visão subnormal, doenças da retina, da córnea, métodos de prevenção, etc., etc.) outras finalidades devem ter, nele, provimento de espaços e tempos. Assim, as para exame de como vai o ensino da Oftalmologia no Brasil, as das políticas junto a convênios de saúde e administração de serviços, as de incentivo à pesquisa e à sua divulgação, etc. Nunca, antes, os debates sobre tais temas "paralelos" se tornaram tão necessários como agora e certamente, sempre, no futuro, ficarão cada vez mais importantes. É pois nesse contexto amplo que se situa a valorização da formação de quadros editoriais, um reflexo da complexidade com que se vão diferenciando as vertentes do Conselho Brasileiro de Oftalmologia. Um inequívoco sinal de crescimento necessário e de progresso equilibrado.

Mas, afinal, sobre o Simpósio propriamente dito: desenvolveu-se ele em duas partes. Na primeira, expositiva, os editores dos A.B.O. discorreram sobre temas abrangidos pelo título "A importância e a função de um conselheiro editorial” direcionados à informação de como analisar os artigos encaminhados aos A.B.O. Apesar de os alvos das exposições serem pessoas já inseridas no conhecimento da matéria e com experiência sobre ela, 40 assinaram uma lista de presença aos trabalhos (e é provável que outras mais não o tenham feito). Tal assistência demonstra um interesse seletivo dessas pessoas sobre um tema tão específico, o que lhes é altamente lisonjeiro. E, no que nos diz respeito, torna-se bastante encorajador sabermos que elas estão cada vez mais se qualificando a levar a editoração nacional aos níveis desejados e merecidos de excelência.

Mais importante, porém, foi a parte que se seguiu, o Fórum de Conselheiros Editoriais e assessores “ad hoc”, com a participação dos então presentes. Várias sugestões foram apresentadas e debatidas, notando-se, nelas, o interesse genuíno de contribuição para a melhoria dos padrões de qualidade dos A.B.O. Ainda que algumas propostas dependam de mais verbas e funcionários para suas implementações, a maioria das apresentadas parece exeqüível com os recursos atuais, devendo ter então aplicações imediatas. E nessa importante ouvidoria da comunidade editorial, cujo empenho tem sido a sustentação dos índices de qualidade dos A.B.O., chegou-se à solução já comentada no editorial anterior sobre como dar continuidade à sua política de publicações: pelo menos provisoriamente, dar mais volume a nossos fascículos, acolhendo mais artigos, sem perdas de exigibilidades em suas análises.

É assim que se pretende a continuidade dos A.B.O.: com uma forte interação entre seus protagonistas (leitores, autores, consultores, editores) e seus administradores (Conselho Administrativo e Diretoria do C.B.O.). 